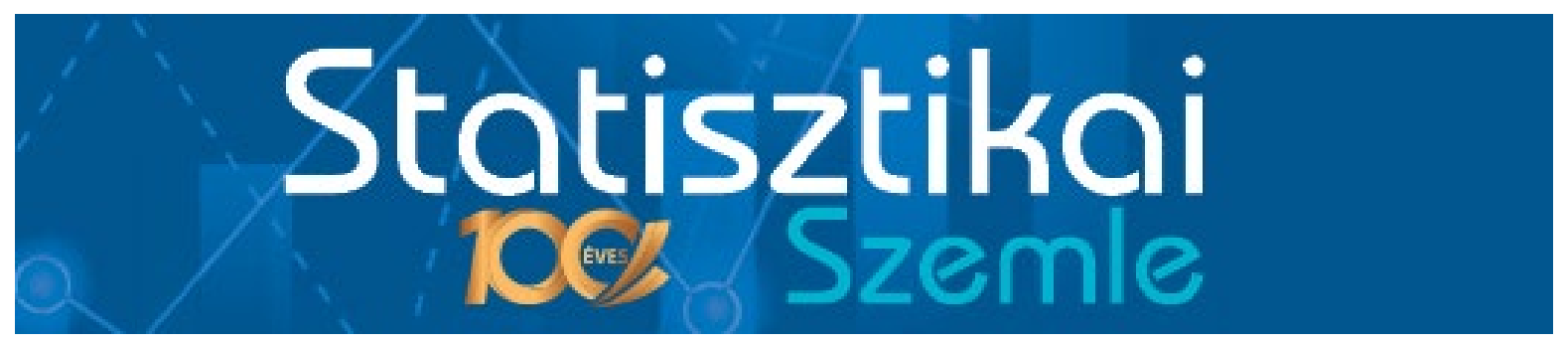

Közzététel: 2022. január 14.

A tanulmány címe:

\title{
A magyar lakbérstatisztika története
}

Szerző:

ErTl ANTAL,

a Központi Statisztikai Hivatal szakstatisztikusa, a Budapesti Corvinus Egyetem PhD-hallgatója E-mail: Antal.Ertl@ksh.hu

DOI: https://doi.org/10.20311/stat2022.1.hu0068

Az alábbi feltételek érvényesek minden, a Központi Statisztikai Hivatal (a továbbiakban: KSH) Statisztikai Szemle c. folyóiratában (a továbbiakban: Folyóirat) megjelenő tanulmányra. Felhasználó a tanulmány vagy annak részei felhasználásával egyidejüleg tudomásul veszi a jelen dokumentumban foglalt felhasználási feltételeket, és azokat magára nézve kötelezőnek fogadja el. Tudomásul veszi, hogy a jelen feltételek megszegéséből eredő valamennyi kárért felelősséggel tartozik.

1. A jogszabályi tartalom kivételével a tanulmányok a szerzői jogról szóló 1999. évi LXXVI. törvény (Szjt.) szerint szerzői münek minősülnek. A szerzői jog jogosultja a KSH.

2. A KSH földrajzi és időbeli korlátozás nélküli, nem kizárólagos, nem átadható, térítésmentes felhasználási jogot biztosít a Felhasználó részére a tanulmány vonatkozásában.

3. A felhasználási jog keretében a Felhasználó jogosult a tanulmány:

a) oktatási és kutatási célú felhasználására (nyilvánosságra hozatalára és továbbítására a 4. pontban foglalt kivétellel) a Folyóirat és a szerző(k) feltüntetésével;

b) tartalmáról összefoglaló készítésére az írott és az elektronikus médiában a Folyóirat és a szerző(k) feltüntetésével;

c) részletének idézésére - az átvevő mü jellege és célja által indokolt terjedelemben és az eredetihez híven - a forrás, valamint az ott megjelölt szerző(k) megnevezésével.

4. A Felhasználó nem jogosult a tanulmány továbbértékesítésére, haszonszerzési célú felhasználására. Ez a korlátozás nem érinti a tanulmány felhasználásával előállított, de az Szjt. szerint önálló szerzői münek minősülő mü ilyen célú felhasználását.

5. A tanulmány átdolgozása, újra publikálása tilos.

6. A 3. a)-c.) pontban foglaltak alapján a Folyóiratot és a szerző(ke)t az alábbiak szerint kell feltüntetni:

„Forrás: Statisztikai Szemle c. folyóirat 100. évfolyam 1. számában megjelent, Ertl Antal által írt, 'A magyar lakbérstatisztika története' címü tanulmány (link csatolása)"

7. A Folyóiratban megjelenő tanulmányok kutatói véleményeket tükröznek, amelyek nem esnek szükségképpen egybe a KSH vagy a szerzők által képviselt intézmények hivatalos álláspontjával. 


\section{Ertl Antal}

\section{A magyar lakbérstatisztika története*}

\section{The history of Hungarian housing rent statistics}

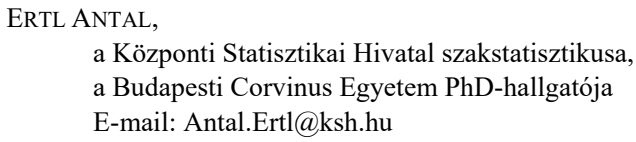

A tanulmány a hazai lakásbérléssel kapcsolatos statisztikai adatgyüjtés történetét foglalja össze. Bár a lakásstatisztika elsődlegesen a lakásállományt, a lakásépítés trendjeit, illetve a lakáspiaci árak alakulását méri fel, a lakbérstatisztikáról is fellelhetők korai megfigyelések: már az Osztrák-Magyar Monarchia idején készült a bérleményekről összeírás Budapesten, és a XX. század 30-as éveiben is találunk példát a téma alapos feltárására, vonatkozásainak végiggondolására. A korabeli statisztikusok megalapozták az adatok gyüjtésének módszertanát, világos koncepciót fogalmaztak meg azok felhasználására, és társadalompolitikai ajánlásokat is tettek. A lakásbérleti statisztikák a szocialista Magyarországon háttérbe szorultak, azonban a rendszerváltással újra középpontba kerültek. A szerző a történeti áttekintésen túl a mai lakbérstatisztika módszertanát, illetve lehetséges fejlődési irányait is ismerteti.

TÁRGYSZÓ: lakásstatisztika, lakbér, lakásgazdaságtan

The study summarises the history of the Hungarian statistical data collection on house renting. Although housing statistics primarily measure the stock of housing and the trends in housing construction and prices, one can also find early observations on rental statistics. A census of leaseholds was already taken during the Austro-Hungarian Monarchy, and there are examples from the 1930s of a thorough exploration of the topic and its implications. The statisticians at the time developed the methodology of data collection, formulated a clear concept for their use, and made recommendations on social policy. In the socialist era, housing rental statistics were pushed into the background, but with the change of regime, they became the focus again. In addition to the historical overview, the author describes the methodology of modern rent statistics and the possible directions for development.

KEYWORD: housing statistics, housing rents, economics of housing

* A szerző köszönetét fejezi ki Székely Gábornénak a kutatás során adott javaslataiért és segítségéért.

STATISZTIKAI SZEMLE, 100. ÉVFOLYAM 1. SZÁM 68-91. OLDAL DOI: 10.20311/stat2022.1.hu0068 
A lakáspiac az utóbbi évek egyik legfelkapottabb közpolitikai témájának számít: köszönhető ez egyrészt az amerikai másodrendü-lakáshitelek szerepének a 2008-as pénzügyi válságban, másrészt pedig annak, hogy a lakhatás megfizethetőségével számos kutatás foglalkozik. Thomas Piketty [2014] a társadalmi egyenlötlenségek vizsgálatát arra a (mára már híressé vált) feltevésre építette, hogy a tőkéből származó jövedelmek növekedési üteme meghaladja a jövedelmek növekedését, ezáltal fokozva az egyenlőtlenséget a tőkejövedelemmel és a kizárólag munkabérből származó bevétellel rendelkezők között. Tanulmányában Piketty a lakáspiacon tőkejövedelemként alapvetően a lakóingatlanok értékének növekedésével járó vagyonhatást definiálta, azonban nem számolt az ingatlanból származó bevételekkel.

Bonnet et al. [2014] kritizálták Piketty lakáspiaci megközelítését, mivel szerintük leegyszerüsítette a problémát azzal, hogy kizárólag a lakásárak növekedésére koncentrált az egyenlőtlenségek vizsgálatánál. A szerzők szerint a lakbérek pontosabb képet adnak az egyenlőtlenségekröl, mivel ezek reprezentálják a lakástulajdonosok tőkejövedelmét, amely vagy bevételként vagy megtakarításként, azaz nem kifizetett lakbérként jelenik meg a háztartások költségvetésében. A lakbérekböl több nyugateurópai országra stabil tökejövedelem/jövedelem arányt számítottak (kivéve Németországra, ahol ez az arány nőtt). Azonban ez sem feltétlen pontos becslés, lévén a lakástulajdonosoknak az ingatlanuk értékcsökkenése miatt kiadásaik is vannak - azaz karbantartásokat kell végezniük.

Ez a példa jól mutatja a lakbérek nem triviális mibenlétét a lakáspiacon. A lakbérek vizsgálatánál hajlamosak vagyunk gazdasági elemzőkként a lakhatási megfizethetőséget mérni, azonban a lakbérek alakulását egyéb célokra is fel lehet használni. A lakbérek és a lakásárak kapcsolatának, valamint egymásra való hatásuknak széles körü irodalma van, amelyet a makroökonómiában például a Gordon-modellel írnak le (Campbell-Shiller [1988]).

Magyarországon a lakásbérleti szektor megfigyelése 1949 után okafogyottá vált, és emiatt úgy tünhet, a rendszerváltást követő mérési kísérletek előzmény nélküliek, azonban ez távolról sem igaz: a lakbérek összeírása majdnem egyidős a fővárosi statisztikai hivatallal.

Tanulmányom első fejezetében a magyarországi lakbérstatisztika második világháború előtti történetét foglalom össze röviden, bemutatom a lakbér definíciójának és közlésének módszertani megfontolásait, melyeket Szádeczky-Kardoss Tibor 1933-as írásában fejtett ki. A második és harmadik fejezetben azt ismertetem, hogy miként alakult a lakbérstatisztika a XX. század második felétől, illetve a rendszervál- 
tozás után. Külön kitérek a KSH (Központi Statisztikai Hivatal) és az ingatlan.com lakbérindex-fejlesztésére, illetve az ezt megalapozó hazai kutatásokra. Végül külföldi példákon keresztül veszem górcső alá a lakbérstatisztika potenciális felhasználási területeit.

\section{Lakbérstatisztika a második világháború előtt}

„Az 1870-ben megalakult Budapest Székesfőáros Statisztikai Hivatala (Fővárosi Hivatal) volt az európai fövárosok statisztikai hivatalai közül az első, amely kialakította a lakásépítési statisztikát." (Farkas [2000] 845. old.) Ekkor párhuzamosan létezett országos és fővárosi statisztikai hivatal; utóbbi irányította a budapesti népszámlálásokat, melyekben az országos népszámlálási adatok mellett egyéb kérdéseket is feltettek a fővárosiaknak (Kígyósi [2007]). Az országoson kívül a Fővárosi Statisztikai Hivatal 1906-ban, 1925-ben és 1935-ben külön népszámlálást bonyolított le Budapesten (Lencsés [2012]).

Már az 1870-es népszámlálás budapesti adatfelvétele során megtörtént az épületek és lakások helyiségek szerinti összeírása. Ezt nem sokkal később követte a fővárosban üresen álló lakások állományát és lakbérének alakulását felmérő statisztikai adatgyüjtés, amely a fövárosi hivatalt vezető Körösy József nevéhez füződik. A felmérésben az üres lakásokat szobák szerint, valamint éves bérleti díj (lakbér) alapján csoportosították, és eszerint közölték az elemszámokat. Azonban ez az adatgyűjtés még nem nyújtott érdemi információt a budapesti ténylegesen lakott lakások lakbéréről, az üresen álló lakások lakbérének szintje nem tükrözte a tényleges lakbérviszonyokat. Ez egyrészt abból adódott, hogy viszonylag kis lakástömeget érintett a felmérés, az üres lakások strukturális jellemzői eltértek a kibérelt lakásokétól (például távol estek a városközponttól, vagy új bérlakások voltak, amelyekbe még nem költöztek lakók), másrészt pénzügyi megfontolások (például a túl magas hirdetési ár) is állhattak mögötte, mivel - ahogy a korabeli statisztikusok is megjegyezték - a túl magas kínálati ár mellett a lakást nem veszik ki bérlők, ami alapján az adatgyüjtés felfelé torzító képet mutathat a budapesti lakásbérleti piacról.

Az 1906. évi Budapestre érvényes népszámlálás az első, amely a lakbérstatisztikai adatok szinte teljes körét felmérte 148886 budapesti lakás bérének összeírásával (Budapest Székesfóváros Statisztikai Hivatala [1914]). A lakások bérértékét az üresen álló és a tulajdonosok által lakott lakásokra is számba vették a tényleges bérlemények mellett. A lakásokat helyiségek szerint írták össze (az összeírók számára pontosan definiálták, hogy mi számít helyiségnek), azonban nem gyüjtöttek adatokat a mellékhelyiségek (mint például cselédszoba, előszoba) meglétéről és számáról.

STATISZTIKAI SZEMLE, 100. ÉVFOLYAM 1. SZÁM 68-91. OLDAL DOI: 10.20311/stat2022.1.hu0068 
E probléma következményeivel már az akkori statisztikusok is tisztában voltak: példának hozták fel a müncheni lakbérstatisztikát, ahol a mellékhelyiségeket nem számítva hatalmas volt a lakbérek közötti szórás (Szádeczky-Kardoss [1933]). Kitértek továbbá a nemzetközi (és a Monarchián belüli) összehasonlítás nehézségeire is, ti. például a bécsi és budapesti lakások szobáinak nagysága merőben eltért egymástól. A korabeli statisztikákban már a lakásnyomort is igyekezték mérni, melyhez alapvetően a lakósürüséget használták, köbméterben kifejezve (Bresztovszky [1909]).

Az 1906. évi budapesti népszámlálás két kategóriát különített el a lakbérek összegzésénél: a konyhás és konyhátlan lakásokat. A konyhátlan lakások jóval nagyobb lakbérüek voltak, erre a tényre a korabeli statisztikusok-elemzők két magyarázatot adtak. Egyrészt a konyha nélküli lakások esetén előfordult, hogy elsődlegesen nem lakásként, hanem mühelyként, munkahelyként funkcionáltak, mellékesen pedig lakhattak bennük inasok és cselédek. Másrészt hivatkoztak arra az empíriára, mely szerint az ilyen lakásokban jellemzően nagyobb volt a túlzsúfoltság aránya; a lakbérfelárból, valamint a nagyobb zsúfoltságból pedig a lakásuzsorások meglétére lehetett következtetni. Így a tényleges lakbérek elemzésénél alapvetően a konyhával rendelkező lakásokat vették figyelembe, melyek számát, bérértékét és egy helyiségre jutó bérértékét is közölték. Ezen adatokat kerületi bontásban is összegezték, mivel így homogénebb csoportokat kaphattak, és a bérlemények területi dimenzióit is elemezhették.

1. ábra. Példa az átlagos évi bérértékek közlésére az 1906-os budapesti népszámlálásban (Example of average wage values reported in the 1906 Budapest census)

A rendes lakásoknak átlagos évi bérértéke.

Durchschnittlicher Mietzins der gewöhnlichen Wohnungen.

\begin{tabular}{|c|c|c|c|c|c|c|c|c|c|}
\hline \multirow{2}{*}{$\begin{array}{c}\text { Lakások nagysága } \\
\text { helyiségeik száma } \\
\text { szerint } \\
\text { Grösse der Wohnun- } \\
\text { gen nach đer Anzahl } \\
\text { der Localitaten }\end{array}$} & \multicolumn{3}{|c|}{$\begin{array}{c}\text { Konyhás lakások }{ }^{1} \text { ) } \\
\text { Wohnungen mit Kächen }\end{array}$} & \multicolumn{3}{|c|}{$\begin{array}{c}\text { Konyhátlan lakások }{ }^{1)} \\
\text { Wohnumgen ohne Küchen }\end{array}$} & \multicolumn{3}{|c|}{ Összesen - Zusammen ${ }^{1}$ ) } \\
\hline & $\begin{array}{c}\text { Lakások } \\
\text { száma } \\
\text { Anzahl der } \\
\text { Wohnungea }\end{array}$ & $\begin{array}{c}\text { Évi bérérték } \\
\mathbf{K} \\
\text { Jahres- } \\
\begin{array}{c}\text { Mietzins- } \\
\text { wert K }\end{array}\end{array}$ & $\begin{array}{c}\text { Átlagos } \\
\text { bérértek K K } \\
\text { Durrechschnitt. } \\
\begin{array}{c}\text { Mietzins } \\
\text { wert K }\end{array} \\
\end{array}$ & $\begin{array}{c}\text { Lakảsok } \\
\text { száma } \\
\text { Anzahl der } \\
\text { Wobnungen }\end{array}$ & \begin{tabular}{|c|}
$\mid$ Évi bérérték \\
$\mathbf{K}$ \\
Jahres- \\
Mietzins- \\
wert K
\end{tabular} & $\begin{array}{c}\text { Attlagos } \\
\text { bérértekk K } \\
\text { Durchschnitt. } \\
\begin{array}{c}\text { Mietzing- } \\
\text { wert K }\end{array} \\
\end{array}$ & $\begin{array}{c}\text { Laká } \\
\text { szá } \\
\text { Anzah } \\
\text { Wohnt } \\
\end{array}$ & \begin{tabular}{|c|} 
Evi bérérték \\
$\mathrm{K}$ \\
Jahres- \\
Mietzins- \\
wert K
\end{tabular} & 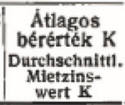 \\
\hline 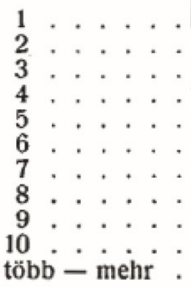 & $\begin{array}{r}131 \\
67.856 \\
22.616 \\
15.332 \\
9.968 \\
10.181 \\
6.081 \\
2.736 \\
1.258 \\
614 \\
972\end{array}$ & $\begin{array}{r}17, \\
9, \\
9, \\
7, \\
10, \\
8, \\
4, \\
2, \\
1, \\
2\end{array}$ & $\begin{array}{l}1 \\
2 \\
4 \\
5 \\
7\end{array}$ & $\begin{array}{r}9.457 \\
906 \\
341 \\
151 \\
107 \\
49 \\
41\end{array}$ & $\begin{array}{r}350 \\
180 \\
151 \\
114 \\
64 \\
106 \\
89 \\
39 \\
66 \\
143\end{array}$ & & $\begin{array}{r}2.764 \\
1.270 \\
632 \\
1.003\end{array}$ & $\begin{array}{r}8,02 \\
10,88 \\
8,50 \\
4,93 \\
2,75 \\
1,55 \\
3,42\end{array}$ & 3.414 \\
\hline Össz. - Zus. & 'i) 137.74 & $75,251.500$ & 5 & 1) 11.141 & $3,097.460$ & & 148.8 & $78,348.060$ & 526 \\
\hline
\end{tabular}

Forrás: Budapest Székesföváros Statisztikai Hivatala ([1914] 43. old.). 
Külön érdekesség, hogy az 1906-os budapesti adatgyüjtés során megkísérelték feltérképezni az albérlőket és az ágybérlőket is. Az adatok alapján a szakemberek a következö megállapításra jutottak: számos háztartás nyerészkedett az albérlőkön, azaz az albérlőkkel majdnem kifizettették a teljes lakbért, egyes esetekben még többet is. Ezt a tényt a lakásuzsora újabb bizonyítékaként könyvelték el.

Az 1920-as és 1925-ös budapesti lakásösszeírások alkalmával részben változtattak a metóduson: ekkor csupán a ténylegesen bérlők által lakott lakások lakbérét írták össze, beleértve az albérlőket és az ágybérlőket is. Szádeczky-Kardoss [1933] azonban megjegyezte: az első világháború utáni kötött lakásforgalom miatt ezek az adatok torz képet festenek a tényleges piaci viszonyokhoz képest. Az 1930. évi országos népszámlálás budapesti adatainak feldolgozásakor a lakbérek csoportosítását a korábbiakhoz képest - társadalomkutatási és történeti okokra hivatkozva kiegészítették a társadalmi rétegződés és a házak építési ideje szerinti csoportosítással. Szádeczky-Kardoss [1933] részletesen ismertette a Budapestre vonatkozó népszámlálás során alkalmazott módszertant és annak indoklását. Ezen módszertani megfontolásokról a továbbiakban bővebben is szót ejtünk.

\subsection{Az 1930-as budapesti lakbérfelmérés; a lakbérstatisztika módszertani megfontolásai}

Az elmúlt több mint száz évet felölelően igen nehéz időbeli összehasonlítást végezni a lakbérek alakulásáról. Ennek oka az adatgyüjtés módszertanának változása például az 1906-os és az 1930-as budapesti lakásfelmérés között a helyiségek definíciója módosult. Ugyanakkor a szabályozási aspektusok sem elhanyagolhatók - például az első és a második világháború után is szabályozottak voltak a lakbérek (ezekre később részletesen is kitérek).

A lakbérek vizsgálata során számtalan triviális és nem triviális módszertani akadályba ütközhetünk. Ilyen például az ingatlanpiac változása: a modern lakásbérlésnél elég nehezen képzelhető el, hogy egy konyha nélküli lakás többet érjen, mint egy konyhával rendelkező. A statisztikusok a módszertani anomáliák némelyikét már a múlt század elején felismerték, és mérlegelték a lehetséges megoldásokat. A továbbiakban az 1930-as részletes lakbérfelmérést, valamint annak módszertani megfontolásait ismertetem Szádeczky-Kardoss [1933] tanulmánya alapján.

Az első probléma magából a lakbér definiálásából eredt. A statisztikai adatgyüjtés tervezése során le kell szögeznünk, hogy miként értelmezendő az albérleti díj: csak az ingatlanért fizetett árat vagy az egyéb ingatlannal kapcsolatos költségeket is tartalmazza. Még így is előfordulhat, hogy a megkérdezett albérlő, illetve főbérlő nem különíti el a két összeget az árazásnál, és a bérleti díjhoz számítja a fenntartási

STATISZTIKAI SZEMLE, 100. ÉVFOLYAM 1. SZÁM 68-91. OLDAL DOI: 10.20311/stat2022.1.hu0068 
költséget is. Ennek következményeként azonban elöfordulhat, hogy nem egységes adatokat kapunk. Szádeczky-Kardoss példaként hozta fel, hogy a fővárosban különböző lakások és területek szerint eltérően számolták el a csatorna- és fütési díjakat: néhol beszámították a lakás bérleti díjába, máshol azonban havonta keletkező fix díjként könyvelték el, amelyet a főbérlő fizetett.

Gondot okozhatott még az is, ha a lakást gazdasági tevékenységre, üzletként vagy mühelyként hasznosították. Szádeczky-Kardoss [1933] érve szerint miután a lakás bérleti díja fontos részét képezi a létfenntartási költségnek, egy üzlet bérleti díja pedig adott gazdasági szervezet müködési költségeihez tartoznak, ezért ezt a két eshetőséget el kell különíteni egymástól, és csak az előbbit szabad figyelembe venni (ennek megfelelően lehet példát találni olyan esetekre, amikor a statisztikai adatgyüjtés kiterjedt az üzlethelyiségekre, azonban azok bérleti díját külön közölték a lakbérektől). A megkülönböztetés egyszerünek tünhet, ha kizárólag éttermeket, raktárhelyiségeket és kisebb üzleteket akarunk az adatgyüjtésünkből leválogatni például alapterület szerint.

A lakásbérleti díjak mértékének egyik legfontosabb tényezője a bérelt lakás nagysága. Hasonlóan a lakástranzakciókban használt négyzetméterárhoz, a négyzetméterre jutó lakbér is fontos mérőszám lehet; az ár és alapterület közötti összefüggés a lakáspiacon széles körben ismert, az ökonometriában tankönyvi példának számít. A lakásnagyságot a hasznos vagy a teljes alapterülettel (esetenként fütött alapterülettel) szokás mérni, azonban a második világháború előtt a statisztikai adatgyüjtés bevett módszere a helyiségek száma szerinti kérdezés volt.

Sokáig nem volt egyezményes módszer a helyiségek osztályozására és figyelembevételére. Szádeczky-Kardoss a német lakásstatisztikát említi példaként: 1910 előtt csak a füthető szobák szerint csoportosította a német statisztikai hivatal a lakbéreket. Ennek a módszernek azonban az volt a hátránya, hogy nem vette figyelembe azokat a szobákat, amelyeket bár nem fútöttek (például a mellékhelyiségek, kamrák stb.), mégis jelentősen hozzájárultak az ingatlanok minőségéhez és árához. Így 1910-től az emberek által élhető, fütött lakóhelyiségek szerinti csoportosítást választotta a hivatal (Ascher [1918] tanulmányát idézi Szádeczky-Kardoss [1933]). Azonban magyar példa is hozható a „helytelen” csoportosításra: ahogy már korábban említettük, az 1906-os budapesti népszámlálás lakbéradatainál nem különböztették meg a lakó-, illetve mellékhelyiségeket. Szádeczky-Kardoss szerint ez azért kifogásolható, mert így a lakó- és a mellékhelyiségek hatása nem mérhető fel, amellett, hogy nyilvánvalóan a lakóhelyiségek száma nagyobb hatással van a lakbér alakulására. Pontosan ezen indokok miatt az 1930-as lakásstatisztikai felvételnél már külön kezelték a lakó- és az egyéb helyiségek számát.

Szádeczky-Kardoss [1933] munkájából kitünik, hogy a korabeli szerzők tisztában voltak a külföldi (elsődlegesen a német és az osztrák, de több más nyugateurópai) szakirodalom kutatási eredményeivel. Az akkori kiadványok sajátossága,

STATISZTIKAI SZEMLE, 100. ÉVFOLYAM 1. SZÁM 68-91. OLDAL DOI: 10.20311/stat2022.1.hu0068 
hogy nemcsak deskriptívek voltak, hanem szociológiailag érzékenyen, társadalompolitikai és közgazdasági gondolkodással, valamint ajánlásokkal álltak az adott témakörhöz. Szádeczky-Kardoss a lakbérimputálás alapgondolatát írta le, jó fél évszázaddal korábban, mint ahogy az a hazai statisztika gyakorlatává vált (HüttlPozsonyi [2018], Székely [2020]). A szerző már akkor jelezte, hogy az egyes háztartások kiadásainak értékelésénél az egy före jutó lakbért kellene alkalmazni, valamint kitért arra is, hogy magas albérletárak esetén miként alakul az albérlö-főbérlő viszony a gazdasági egyenlőtlenségek szempontjából. Utóbbira példának hozta fel Lindermann [1902] tanulmányát, melynek tárgya, hogy az albérlők által fizetett lakbérek a föbérlők lakbérének hány százalékát adják. Szádeczky-Kardoss tehát a jövedelmi viszonyok és a lakbérek közötti összefüggést vizsgálta nemcsak hazai viszonylatban, de nemzetközi összevetésben is. Ugyanakkor a lakáspiaci összefüggések elemzése során rendre olyan problémákba ütközött, amelyeket az akkori statisztikai eszköztárral nem lehetett tovább vizsgálni.

A szerző kifogásolta, hogy a kötet írásáig elenyésző volt azoknak a statisztikai vizsgálatoknak a száma, amelyek a lakások minőségéröl, fütési rendszeréről, illetve felszereltségéröl tudakozódtak. Az olvasóban bizonyára felmerül, hogy nemcsak az adatok, de a ma ismert többváltozós elemzési technikák is hiányoztak, SzádeczkyKardoss pedig nyilvánvalóan érzékelte is a további számítási lehetőségek hiányát, az egymást erősítő vagy éppen kioltó hatások szétválasztását. Mára a lakásstatisztikában általánosan elfogadottá vált az ún. hedonikus módszer, melynek alapgondolata pont ezen megfigyelésre, a lakásminőség-változók bevonására épül (Békés-HorváthSápi [2016], Vita [2000], Horváth-Székely [2009]). Az eljárás lényege, hogy az ingatlanok áremelkedésének mérése különböző minőségi tényezők bevonásával (falazat, fütési rendszer, felújított-e stb.) pontosítható, így precízebb lakásárindexek létrehozására alkalmas.

Az 1930-as népszámlálás során három fontos minőségi változót vettek figyelembe a statisztikusok. Az első kettő a térbeli elhelyezkedéssel kapcsolatos: az adott épület lokációja, illetve házon belül a lakás elhelyezkedése (azaz földszinten, emeleten, tetötérben stb. helyezkedik-e el). Ezzel kapcsolatban a nemzetközi irodalommal megegyező az a fö megállapítás, hogy horizontálisan kívülről befelé, vertikálisan lentről felfelé drágulnak a lakbérek - azaz minél beljebb helyezkedik el a belváros irányába, és minél magasabban van lakásunk, annál drágább a bérleti díja. A harmadik minőségi változó az épületek kora, a ház építési éve; erre azonban nem csak az épület minőségének vizsgálatához volt szükség. Magyarországon a két világháború közötti években az 1920 elött épült házakban fizetendő bérleti díjat szabályozták, amely nem terjedt ki az ennél újabb épületekre - így az összesített statisztikákban eleve felmerült az építési évek ezen elvhez igazodó csoportosítása. Mindazonáltal a korabeli statisztikusok tisztában voltak az új lakások nyújtotta minőségbeli különbségek árnövelő hatásával.

STATISZTIKAI SZEMLE, 100. ÉVFOLYAM 1. SZÁM 68-91. OLDAL DOI: 10.20311/stat2022.1.hu0068 
Már a XIX. század közepén megjelent a jövedelem és a kiadások közötti kapcsolat feltérképezésének igénye; az ezzel foglalkozó nemzetközi irodalmat jól ismerte a hazai statisztikus szakma, így Szádeczky-Kardoss is. Engel [1857] törvénye kapcsolatot vélt felfedezni a háztartások jövedelme és az élelmiszer-kiadások között: a jövedelemmel párhuzamosan nominálisan növekvő a háztartásonkénti élelmiszer-kiadás, jövedelemarányosan azonban csökkenő tendencia figyelhető meg. Hasonló kapcsolat fedezhető fel a lakbérek esetén is: minél alacsonyabb a háztartás jövedelme, annál olcsóbb bérleményt keres; azonban jövedelemarányosan a lakhatásra költött összeg egyre magasabb, azaz a szegények a jövedelmük nagyobb részét kénytelenek lakhatásra költeni. Mint Szádeczky-Kardoss írta, a hatást Schwabe [1868] nyomán Schwabeféle törvénynek nevezték el, melynek alátámasztására Singer [1937] készített tanulmányt az Egyesült Államokra, Angliára, Németországra és Franciaországra vonatkozóan: egy bizonyos rétegig megfigyelhető volt a csökkenő lakhatási költséghányad, azonban a középosztály és afelett újra növekvőnek bizonyult. Utóbbi jelenséget Singer a Veblen-jószágok fogyasztásával hozta összefüggésbe. Singert megelőzve hasonló következtetésre jutott Szádeczky-Kardoss is, aki a Schwabe-törvény törékenységét azokra a középosztálybeli háztartásokra vezette vissza, akiknek tisztviselőként viszonylag alacsonyabb jövedelem mellett nagyobb lakásigényük volt. Egy további érdekességre is felhívta a figyelmet, nevezetesen, hogy a kislakások bére olykor magasabb, mint a nagyobbaké. Ezt a szerző egyrészt azzal magyarázta, hogy egy kislakás építési és fenntartási költségei aránylag magasabbak, másrészt a kisebb lakásokban általában többen is laknak, gyakoriak a költözések, így rongálások is előfordulnak, valamint nagyobb a nemfizetés kockázata. Ez a megállapítás ékes példája annak, hogy a korokon átívelő statisztikai elemzéseknél milyen problémák léphetnek fel az árak objektívnek hitt összehasonlítása során, azaz fennáll a lehetősége annak, hogy eltérő piaci viszonyok között próbálunk összehasonlítást végezni.

Sok tényezö tekintetében Szádeczky-Kardoss [1933] tanulmánykötete elöremutató, ugyanakkor tartalmaz olyan részletekbe menő elemzéseket is, amelyek megállapításai - bár általánosan elfogadottak voltak - mára kikoptak a gyakorlatból. Erre példa a foglalkozások szerinti felosztás, ami a társadalmi rétegződést hivatott bemutatni. (lásd a 2. ábrát); ezek a kategóriák részben megmaradtak a szocializmus idején is, bár jóval kisebb számmal (például a szellemi foglalkozásúak egy csoportot alkottak, azonban a munkásosztály változatlanul megmaradt). Az 1900. évi népszámlálás során mezőgazdasági, ipari, polgári és más egyéb foglalkozások szerint számították a népesség megoszlását. Szádeczky-Kardoss [1933] a lakott lakások számát aszerint is csoportosította, hogy a) milyen társadalmi rétegbe tartozott a tulajdonos, és $b$ ) milyen lakásbérleti viszonyban használták a lakást.

Az így kapott eredmények alapján szembetünő, hogy 1930-ban a meghatározó lakáshasználat a bérlet volt (83\%). Ezt követően a legnagyobb arányú természetbeni lakásszolgáltatást az állam, illetve az ipari üzemek biztosították dolgozóiknak.

STATISZTIKAI SZEMLE, 100. ÉVFOLYAM 1. SZÁM 68-91. OLDAL DOI: 10.20311/stat2022.1.hu0068 
Az 1930-as években ilyen természetbeni lakások voltak például a Fehérvári úton található rendőrtelepen is. Szádeczky-Kardoss azonban megjegyzi: „Szerencsés fejlődés volna, ha föleg a nagyobb munkáslétszámmal dolgozó gyárak vezetősége a jövőben fokozottabb mértékben gondoskodnék a munkásság jólétének és egészségügyének előmozdítása céljából napfényes, egészséges munkáslakások építéséröl és ily lakásoknak az állandó munkástörzs részére lehetőleg ingyenes vagy legfeljebb mérsékelt lakbér fizetése fejében való átengedéséről. A gyári munkáslakásokra nemcsak a vidéken, a községektől messze fekvő ipartelepeken van nagy szükség, hanem a városokban és föleg fövárosunkban is, ahol a munkásoknak még mindig jelentékeny része a sötét, egészségtelen, de mégis viszonylag drága lakásokban tengődik." (Szádeczky-Kardoss [1933] 45. old.)

Az idézet újabb példa arra, hogy a korabeli statisztikusok gazdaságpolitikai ajánlásokat is megfogalmaztak.

2. ábra. Példa a társadalmi rétegződés vizsgálatára az 1930-as népszámlálásban

(An example of analysing social stratification in the 1930 census)

6. tábla. A lakott, rendes lakások számának megoszlása a lakásbérleti viszony és társadalmi rétegek szerint.

\begin{tabular}{|c|c|c|c|c|c|c|}
\hline \multirow[b]{2}{*}{ Társadalmi retegek } & \multicolumn{5}{|c|}{ A lakott lakasok kozal } & \multirow[b]{2}{*}{ 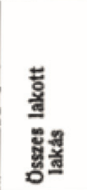 } \\
\hline & 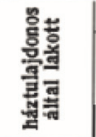 & 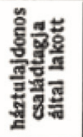 & 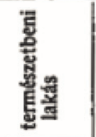 & 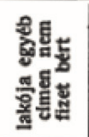 & 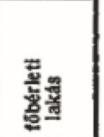 & \\
\hline & \multicolumn{6}{|c|}{ a) Abszolút számokban. } \\
\hline Iparosok & 858 & 129 & 524 & $27 \mid$ & 12.410 이 & 13.948 \\
\hline Kereskedök & 525 & 99 & 60 & 18 & 8.951 & 9.653 \\
\hline tcai ás & 67 & 7 & 39 & 3 & 3.204 & 3.320 \\
\hline Kereskedelmi alkalmazottak & 110 & 67 & 291 & 10 & 9.854 & 10.332 \\
\hline Magántisztviselók & 1.108 & 339 & 1.588 & 103 & 24.445 & 27.583 \\
\hline Köztisztviselók ... & 1.081 & 288 & 1.697 & 173 & 17.044 & 20.283 \\
\hline ati altisztek. & 569 & 30 & 4.031 & 28 & 9.268 & 13.926 \\
\hline Munkások & 1.649 & 464 & 12.939 & 164 & 64.933 & 80.149 \\
\hline Szabadfoglalkozá & 508 & 152 & 112 & 36 & 7.204 & 8.012 \\
\hline Nyugdijasok és vagyonukból êtôk & 2.909 & 378 & 845 & 389 & 22.330 & 26.851 \\
\hline \multirow{3}{*}{$\begin{array}{l}\text { Egyéb és ismeretlen foglalkozásúak ... } \\
\text { Egyutt } \ldots \ldots \ldots \ldots\end{array}$} & 998 & 295 & 4.945 & 105 & 19.108 & 25.451 \\
\hline & 10.382 & 2.248 & 27.071 & 1.056 & 198.751| & 239.508 \\
\hline & \multicolumn{6}{|c|}{ b) Százalékokban. } \\
\hline Iparosok & 6.1! & 0.9 & 3.8 & 0.2 & $89 \cdot 0$ & $100 \cdot 0$ \\
\hline Kereskedok $\ldots \ldots \ldots \ldots \ldots \ldots$ & 5.5. & $1 \cdot 0$ & $0 \cdot 6$ & 0.2 & 92.7 & $100 \cdot 0$ \\
\hline $\begin{array}{l}\text { Piaci és utcai árusok .................. } \\
\text { Kereskedelmi alkalmazottak }\end{array}$ & $\begin{array}{lll}2.0 \\
1.1\end{array}$ & 0.2 & $1 \cdot 2 \cdot 2$ & $\begin{array}{ll}0.1 \\
0.1\end{array}$ & $96 \cdot 5$ & $700 \cdot 0$ \\
\hline Magántisztviselók .. & 4.0 & 1.2 & $5 \cdot 8$ & 0.4 & $88 \cdot 6$ & 100.0 \\
\hline Köztisztviselok ........ & $5 \cdot 3$ & 1.4 & $8 \cdot 4$ & 0.9 & $84 \cdot 0$ & $100 \cdot 0$ \\
\hline Közszolgálati altisztek & 4.1. & 0.2 & 28.9 & 0.2 & $66 \cdot 6$ & $100 \cdot 0$ \\
\hline Munkásol & 2 . & $0 \cdot 6$ & 16.1 & $0 . \overline{2}$ & $81 \cdot 0$ & $100 \cdot 0$ \\
\hline & $6 \cdot 4$ & 1.9 & 1.4 & 0.4 & 89.9 & $100 \cdot 0$ \\
\hline Nyugdijasok és vag & $10-8$ & 1.4 & $3 \cdot 1$ & $1 \cdot 5$ & $83 \cdot 2$ & $100 \cdot 0$ \\
\hline $\begin{array}{r}\text { Egyéb és ismeretlen foglalkozásúak ... } \\
\text { Egyâtt ......... }\end{array}$ & $\begin{array}{c}3 \cdot 9 \\
4 \cdot 4\end{array}$ & $\begin{array}{l}1.2 \\
0.9\end{array}$ & $\begin{array}{l}19 \cdot 4 \\
11.3\end{array}$ & $\begin{array}{l}0.4 \\
0.4\end{array}$ & $\begin{array}{l}75 \cdot 1 \\
83 \cdot 0\end{array}$ & $\begin{array}{l}100 \cdot 0 \\
100.0\end{array}$ \\
\hline
\end{tabular}

Forrás: Szádeczky-Kardoss [1933]. 


\section{Lakbérstatisztika a XX. század második felében}

Lakbérstatisztika a második világháború és a rendszerváltás között szinte nem létezett. Nem azért, mintha a lakásbérlés vagy különösen az albérleti piac megszünt volna, hanem azért, mert a statisztika már nem tekintette feladatának ennek megfigyelését.

A második világháború után, 1949-ben önálló intézményként megszünt a fővárosi statisztikai hivatal, azt követően a KSH területi szervezeteként müködött tovább. Ezzel megszünt számos olyan adatgyüjtés, amely a fővárosi lakáspiaci folyamatokról szolgáltatott információt, például az albérlős és ágybérlős lakásokról vagy a lakásuzsoráról, de hiányosak voltak a megfigyelések az épületek minőségét illetően is (Farkas-Vajda [1990b]). A Magyar Népköztársaság létrejöttének és a magyar statisztika effajta centralizálásának számos következménye volt. Egyrészt a helyi statisztikai hivatalok megszünésével a statisztika érzéketlenné vált az egyéni területi változásokkal szemben (Farkas-Vajda [1990a]). Másrészt - ahogy Farkas és Vajda is kifejti - a háború utáni új, piacgazdaságot felszámoló rendszerben megszüntek hatni azok a piaci mechanizmusok, amelyek a lakástulajdon- és a különböző bérleti díjjal kapcsolatos statisztikák alapját képezik, így sem alapja nem volt az efféle statisztikai közléseknek, sem igény nem jelentkezett ezekre. A világháború után is történtek lakbér-összeírások, ám ezek többségében a tanácsi lakások szabályozott lakbéreire korlátozódtak. A 12840/1948. számú kormányrendelet - hasonlóan a két világháború közötti szabályozáshoz - a háború vége elött épült lakások bérleti díját az 1939. évi árszint háromszorosában, míg az újonnan épült lakásokét szobaszámonként állapította meg. A magánkézben levő lakások bérleti díját (amennyiben az az érvényes jogszabályok szerint szabad bérünek minősült) a tulajdonos szabadon határozhatta meg, azonban a Polgári Törvénykönyv maximalizálta a kiszabható díjat (Rakvács [1974]). Ezen felül rendeletben írták elő a kiszabható lakbérpótlékot is. A szabályozástól függetlenül létezett, ám a hivatalos statisztika alig dokumentálta az egyébként föleg a nagyvárosokban kiterjedt albérletek árviszonyait.

Az 1954-es lakásviszonyokról szóló KSH-jelentés szerint a fővárosban abban az évben 127 ezren éltek albérletekben, valamint mintegy 43 ezer volt az ágyrajárók száma (KSH [1955]). Az 1949 óta eltelt 5 évben közel 30 ezerrel nött a lakásnak használt üzlet-, mühely- és egyéb helyiségekben élők száma. Ekkor a fövárosban jelentős lakáshiány volt, és a megnövekedett belföldi vándorlás következtében a klasszikus értelemben vett albérletek ára számottevően megemelkedett. Valuch [2013] szerint elöfordult havi 300-400 forintos havi szobabérleti díj is, mely lényegesen magasabb volt a lakbéreknél (összehasonlításképp: az államilag szabályozott kétszobás lakások bérlete 113,3 Ft volt); ez az árkülönbség tartósan, az 1980-as évekig fennmaradt. A szocializmus évei alatt végrehajtott népszámlálások

STATISZTIKAI SZEMLE, 100. ÉVFOLYAM 1. SZÁM 68-91. OLDAL DOI: 10.20311/stat2022.1.hu0068 
és mikrocenzusok során ugyan felmérték (például $K S H$ [1986]), illetve egy-egy táblázatban közölték az állami tulajdonú lakások bérleti díjait, valamint az ebből származó bevételeket, azonban a szürkegazdaságban jelenlevő al- és ágybérletekről nem született hivatalos statisztikai adat.

A korábban említett, lakbéreket is szabályozó 1948-as rendeletet 1971-ben felülvizsgálták, ami a lakbérek hirtelen emelkedését eredményezte, melyek 1983-tól évente fokozatosan tovább emelkedtek az állami tulajdonú szektorban (Vértesy [2018]). A rendelet kitért a szabad bérü lakások (azaz az állampolgárok és nem állami szervek tulajdonában levő lakások) bérére is, és ennek maximumát a hasonló komfortfokozatú állami lakások kétszeresében állapította meg; az állami lakások lakbérét szobaszám szerint szabályozta, azonban attól (például elhelyezkedéstől és fekvéstől, valamint müszaki állapottól függően) el lehetett térni (Rakvács [1974]).

A magánpiaci lakbérviszonyok továbbra sem jelentek meg a hivatalos statisztikákban, így lényegében a kor szociográfiai irodalmára maradt a szükös lakásviszonyok között virágzó albérleti uzsora dokumentálása. Az 1950-es éveket követő évtizedekben a munkásszállók és a lakások építésének következtében az ágybérletek száma mérséklődött, az albérletek száma azonban nem csökkent. Az 1960-as évek elején csak Budapesten közel 80 ezren éltek ágy- és albérletekben (Valuch [2013]). Az 1973-as mikrocenzus ( $K S H$ [1974]) csak részlegesen mutatta be a bérlök arányát. A használati jogcím 1960 és 1973 közötti százalékos alakulását ismerteti az 1. táblázat. Területi elhelyezkedés szempontjából érdemes megjegyezni, hogy országosan 1973ban a népesség mintegy 70 százaléka lakott tulajdonosi jogviszonyban, Budapesten ez az arány mindössze 32,6 százalék volt.

1. táblázat

A lakott lakások megoszlása használati jogcím szerint, 1960, 1970, 1973 (százalék) (Distribution of occupied dwellings by occupancy title, 1960, 1970, 1973 [percentage])

\begin{tabular}{l|c|c|c|c|c}
\hline \multicolumn{1}{c|}{ Év } & Összesen & Tulajdonosi & Főbérleti & Társbérleti & Szolgálati \\
\hline 1960 & 100,0 & 62,2 & 32,6 & 1,3 & 3,9 \\
\hline 1970 & 100,0 & 66,5 & 29,4 & 0,5 & 3,6 \\
\hline 1973 & 100,0 & 69,5 & 27,5 & 0,5 & 2,5 \\
\hline Ebből: & 100,0 & & & & \\
\hline Budapest & 100,0 & 32,6 & 63,1 & 1,9 & 2,4 \\
\hline Városok & 100,0 & 60,4 & 37,0 & 0,3 & 2,3 \\
\hline Községek & 100,0 & 88,9 & 8,5 & 0,0 & 2,6 \\
\hline
\end{tabular}

Forrás: KSH ([1974] 58. old.).

Becslések szerint az 1980-as évek elején az ország népességének 3-5 százaléka élt albérlőként (Valuch [2013]), azonban ez a szám föként szobabérlőkre vonatkozott.

STATISZTIKAI SZEMLE, 100. ÉVFOLYAM 1. SZÁM 68-91. OLDAL DOI: 10.20311/stat2022.1.hu0068 
Bár rendelkezünk becsült adatokkal azon személyek számáról is, akik nem saját tulajdonú lakásban éltek, azonban az önálló lakásbérlői arányról nincs pontos adatunk. Az 1984-es mikrocenzus alapján a 3 millió 595 ezres lakásállományból 937 ezret, azaz a teljes állomány több mint 26 százalékát bérleti jogcímen használták. A 937 ezerből 780 ezer tanácsi és 105 ezer egyéb állami tulajdonban levő bérlakást tartottak nyilván; a bérlakások mindössze 5 százaléka tartozott - az akkori szóhasználat szerint - személyi tulajdonba, hiszen magántulajdon nem volt. Az összes bérlakás mintegy 48 százaléka továbbra is Budapesten koncentrálódott ( $K S H$ [1986]).

Az 1984-es mikrocenzus során összeírt lakbéreket az 1930-as évek gyakorlatához hasonlóan árkategóriánként, három csoportban közölték. Elsőként a komfortosságot emelték ki, megmutatva, hogy a komfortfokozat emelkedésével a lakbér is jelentősen nőtt. Másodikként a lakók korösszetétele szerint elemezték a lakbéreket, azonban ez csak korlátozottan értelmezhető: a csoportokat ugyanis az alapján alakították ki, hogy volt-e a lakók között fiatal-, közép- vagy időskorú lakó, azonban a lakók számáról nem állt rendelkezésre információ. Végül a háztartásfő osztályés rétegtagozódása szerint összesítették a lakbéreket. Az 1982. év végi hivatalos adatokat mutatja be a 3. ábra, amelyröl leolvasható, hogy a társadalmi rétegek közül a szellemi foglalkozásúak, illetve a kereskedők éltek a drágább bérủ lakásokban. A bérlakások 57 százalékát a munkásosztály, 37 százalékát pedig a szellemi foglalkozásúak lakták (KSH [1986]): utóbbiak esetén kiemelendő, hogy országos arányukhoz képest többen éltek bérlakásban, ami a lakások fővárosi és városi koncentrációjának tudható be. Mindez egybevág Szelényi és Konrád [1985] megállapításával is, amely szerint a társadalmi elit szerezte meg ezeket a lakásokat.

3. ábra. A bérlakások havi lakbérének megoszlása a háztartásfó osztály-és rétegtagozódása szerint, 1982 (Distribution of monthly rents of rental dwellings by class and social stratification of the head of household, 1982)

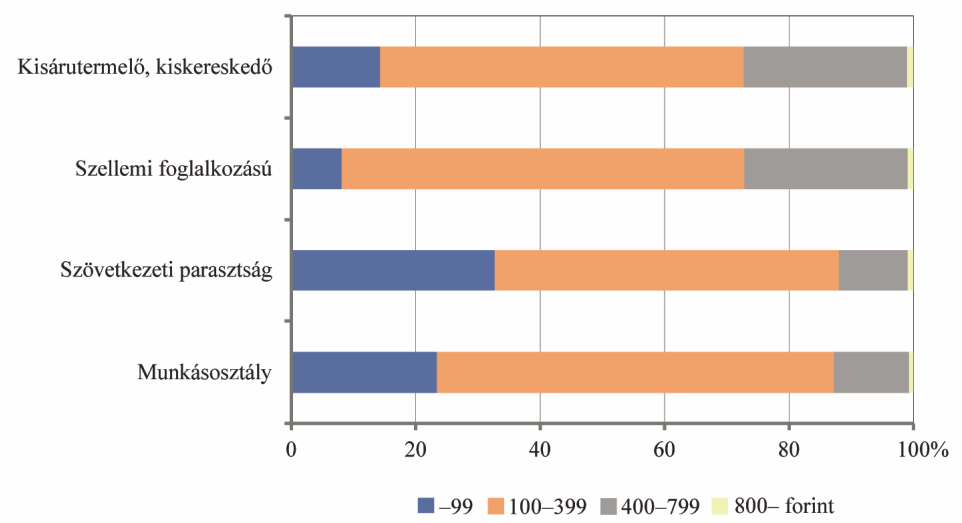

Forrás: KSH [1986]. 
Ebben az időszakban a lakásbérlés ritkán jelent meg statisztikai kiadványokban, bár ez nem jelenti azt, hogy ne lett volna közbeszéd tárgya. Liska [1969] tanulmányában a szocialista bérlakás-politika problémáira hívta fel a figyelmet, és felvázolta bérlakáspiac-tervét, amelyben a bérleményekkel való kereskedést javasolta. A tervet sokan bírálták a nagy bekerülési költségei miatt, melyet például Mihályi [1981] is hangsúlyozott, aki alternatívaként az állami bérlakások, illetve állami lakásberuházások megszüntetését javasolta.

\section{Lakbérstatisztika a rendszerváltozást követően}

1989 után az állami bérlakások számának jelentős csökkenésére, valamint a privát, piaci lakbér legalizálására a hivatalos statisztika is reagált: mind a nemzeti számlákban, mind pedig a fogyasztói árak megfigyelésében szerepet kapott a lakbérstatisztika. 1990 elött az árstatisztika elsősorban termékközpontú volt, a szolgáltatást nagyon kis arányban vette figyelembe, így a lakásbérlés árstatisztikai szempontból nem volt a megfigyelés tárgya. A rendszerváltást követően az inflációs kosárban az immár önkormányzati lakások bérlése mellett megjelent két új reprezentáns, a 30-40 $\mathrm{m}^{2}$-es, illetve az 50-60 $\mathrm{m}^{2}$-es összkomfortos, bútorozott és gépesített magánbérleti lakás. A bérleti díj súlya az inflációs kosárban igen alacsony volt és maradt: az önkormányzati lakásokkal együttesen számított lakbér legnagyobb súllyal 2020-ban szerepelt a fogyasztói árakban, akkor is mindössze 1,4 százalékot képviselt ( $K S H$ [2021]).

Az európai uniós csatlakozás érdekében 1995-től hatályba lépett a nemzeti számlák rendszerében az ESA 1995 (European System of Accounts - Nemzeti Számlák Európai Rendszere) jogszabály, amely új módszertani elvárásokat támasztott a hazai elszámolási rendszerrel szemben. Ennek keretében a nemzeti számlákon belül módosítani kellett a lakásszolgáltatás elszámolását. A lakásszolgáltatást két nagyobb csoportra lehet osztani: egyrészt (önkormányzati és piaci alapú) lakásbérlésre, valamint a tulajdonos saját magának nyújtott szolgáltatására (a tulajdonos mivel saját lakásában él, magának nyújt lakhatási szolgáltatást). Utóbbi elszámolására - lévén, hogy technikai adat - kizárólag becsléseket alkalmazhatunk; erre bevett módszer a piaci bérleti díjak alapján készített imputálás. Magyarországon, illetve több kelet-európai országban azonban ez a fajta számítás nem alkalmazható, mivel rendkívül alacsony a bérlések aránya, a bérleti piac marginális, így a bérelt lakások nem reprezentatívak az ország teljes lakásállományára. A statisztikai hivatal ezért a nemzeti számlák elszámolásánál a 2000-es évek elejétől kezdve a lakbérek helyett az ún. imputált lakbért használja (Hüttl-Pozsonyi [2018]): a lakásszolgáltatás értéke a lakásfenntartási költségekből, illetve a lakás mint befektetési eszköz lehetőségköltségéből számítható.

STATISZTIKAI SZEMLE, 100. ÉVFOLYAM 1. SZÁM 68-91. OLDAL DOI: 10.20311/stat2022.1.hu0068 
Az első kísérleti számítások során fogalmazódott meg az igény a piaci lakbérek megfigyelésére. A feladatot nehezítette, hogy a bérleti lakásokról általában nem áll rendelkezésre mintavételi keret. A rendszerváltást követő első lakbérfelvételre a „Lakbérfelvétel 2000” elnevezésü KSH-összeírás keretében került sor, melynek öszszefoglaló eredményeit a 2. tábla szemlélteti. A felvételt nehezítette, hogy a magánbérleti lakások jóval alacsonyabb arányban (becslések szerint $\sim 3$ százalékban) voltak jelen az országban. Az adatgyüjtéskor elsősorban az 1996-os mikrocenzusból ismert magánbérleti lakásokat vették alapul, ám ez az információ több esetben elavultnak bizonyult. A statisztikákat végül mintegy 2200 cím segítségével állították elö, az eredményeket fajlagos bérleti díj szerint összegezték terület, komfortfokozat és szobaszám szerint. Reprezentatív felmérést azonban csak a 2001. évi népszámlálás után, az akkor azonosított lakcímeken lehetett elöször kivitelezni.

A „Lakbérfelvétel 2000” összefoglaló eredményei (Summary results of the 'Rent Survey 2000')

\begin{tabular}{|c|c|c|}
\hline Jellemző & $\begin{array}{l}\text { Lakbér } \\
\left(\mathrm{Ft} / \mathrm{m}^{2}\right)\end{array}$ & $\begin{array}{l}\text { Összes alapterület } \\
\left(\text { ezer } \mathrm{m}^{2}\right)\end{array}$ \\
\hline \multicolumn{3}{|l|}{ Településtípus } \\
\hline Budapest & 717 & 49392 \\
\hline Városok & 363 & 124766 \\
\hline Községek & 283 & 105881 \\
\hline \multicolumn{3}{|l|}{ Régió } \\
\hline Budapest & 626 & 77030 \\
\hline Közép-Dunántúl & 387 & 29519 \\
\hline Nyugat-Dunántúl & 489 & 27631 \\
\hline Dél-Dunántúl & 264 & 28078 \\
\hline Észak-Magyarország & 253 & 35629 \\
\hline Észak-Alföld & 279 & 40518 \\
\hline Dél-Alföld & 235 & 41634 \\
\hline \multicolumn{3}{|l|}{ Komfortosság } \\
\hline Nem komfortos & 274 & 64718 \\
\hline Komfortos & 432 & 215321 \\
\hline \multicolumn{3}{|l|}{ Szobaszám } \\
\hline 1 & 453 & 19170 \\
\hline 2 & 378 & 105214 \\
\hline 3 és több & 400 & 155655 \\
\hline Összesen & 395 & 280039 \\
\hline
\end{tabular}

Forrás: $K S H$ [2001]. 
A 2002-ben végrehajtott felmérésben mintegy 5 ezer cím felkeresését követően 3 ezer sikeresen összeírt bérleti lakás adata állt elö. Jól illusztrálja a terület változékonyságát, hogy alig egy évvel a népszámlálás után a felkeresett címek negyedén már nem bérleti lakást találtak az összeírók. Az ekkor megfigyelt lakbérek országos átlaga 34 ezer $\mathrm{Ft}$ volt. Budapesten a két lakbérfelvétel között jelentős, mintegy 30 százalékos árnövekedést lehetett megfigyelni. A 2002. évi átlagos lakbéreket a 3. táblázat mutatja.

Atlagos lakbér település- és lakástípus szerint, 2002

(Average rent by type of settlement and dwelling, 2002)

\begin{tabular}{|c|c|c|c|c|c|}
\hline Lakástípus & Budapest & Megyeszékhely & $\begin{array}{c}\text { Város- } \\
\text { agglomerációban }\end{array}$ & Többi város & Összesen \\
\hline & \multicolumn{5}{|c|}{ Ft/lakás } \\
\hline Bérház, nem zöldövezeti többlakásos & 46000 & 32000 & 38000 & 23000 & 38000 \\
\hline Lakótelep & 43000 & 31000 & 38000 & 24000 & 34000 \\
\hline Zöldövezeti többlakásos & 66000 & 33000 & 42000 & 19000 & 57000 \\
\hline Családi ház & 43000 & 32000 & 35000 & 25000 & 30000 \\
\hline \multirow[t]{2}{*}{ Összesen } & 46000 & 32000 & 36000 & 24000 & 34000 \\
\hline & \multicolumn{5}{|c|}{$\mathrm{Ft} / \mathrm{m}^{2}$} \\
\hline Bérház, nem zöldövezeti többlakásos & 954 & 640 & 799 & 450 & 781 \\
\hline Lakótelep & 917 & 636 & 796 & 468 & 696 \\
\hline Zöldövezeti többlakásos & 1136 & 563 & 818 & 385 & 984 \\
\hline Családi ház & 809 & 513 & 682 & 375 & 505 \\
\hline Összesen & 935 & 617 & 733 & 405 & 665 \\
\hline
\end{tabular}

Forrás: $K S H$ [2003].

A 2010-es évektől kezdve egyre növekvő igény merült fel a lakbérekre vonatkozó statisztikai tájékoztatásra. Az újabb felmérést az tette lehetővé, hogy a 2016. évi mikrocenzus rendkívül nagy mintán valósult meg, mely jó alapot biztosított a magánbérleti lakások vizsgálatához. A 2018-as felmérés mintája 15 ezer címet és több mint 500 települést tartalmazott. A kutatásból kiderült, hogy Magyarországon a lakásbérlés döntően a fövárosban és a nagyvárosokban van jelen; ezek az összes piaci bérlakás majdnem 70 százalékát teszik ki, és mintegy 80 százalékuk többlakásos épületben található (KSH [2019]). 2018-ban az átlagos lakbér 83 ezer forint volt, azonban a lakásbérleti díjak balra ferde eloszlást mutattak. Ez látható a 4. ábrán: 
a bérleti díjak jelentős része a 30 ezer és 90 ezer forint közötti tartományban helyezkedik el, a lakbérek 30 százaléka meghaladja a havi 90 ezer forintot.

4. ábra. A lakások bérleti dijának eloszlása, 2018

(Distribution of housing rents, 2018)

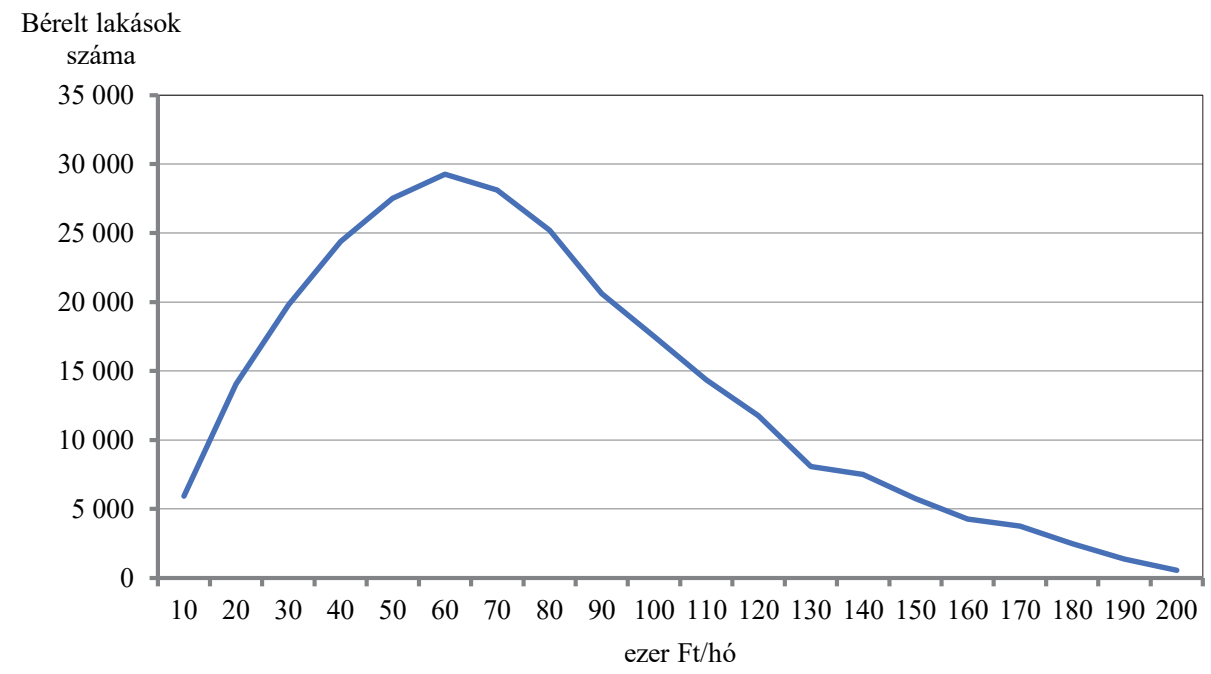

Forrás: KSH [2019].

A kutatás során a bérleti díjakon, illetve a bérelt lakások tulajdonságain kívül a bérleti piac müködésével kapcsolatos számos kérdésre is választ kaptunk, melyekröl a felmérés elött csak külföldi tapasztalatokra támaszkodhattunk. Sor került a bérlők családi állapotának felmérésére (a családi vagy párkapcsolatban élők közel 60 százaléka, az egyedülállók mintegy 30 százaléka bérelt lakást), a lakásbérlés okának, illetve a bérlő és a kiadó kapcsolatának elemzésére. Utóbbi fontosnak bizonyult a bérleti díj alakulásának szempontjából is, amit az 5 . ábra szemléltet: amennyiben a bérlő a lakást ingatlanportálon találta, vagy egyéb internetes forrásból szerezte, úgy az átlagos fizetett bérleti díj szignifikánsan magasabb volt, mint amikor a bérlő és a kiadó személyesen ismerték egymást. Így számszerüsíthetővé vált a (hazai) bérleti piac egyik meghatározó tényezője, a bizalom, mely az árban is egyértelmüen tükröződik. 
5. ábra. Attlagos lakbérek a bérlö és a kiadó közötti kapcsolat létrejöttének módja szerint, településtípusonként, 2018

(Average rents based on the formation of relationship between tenants and landlords, by type of settlement, 2018)

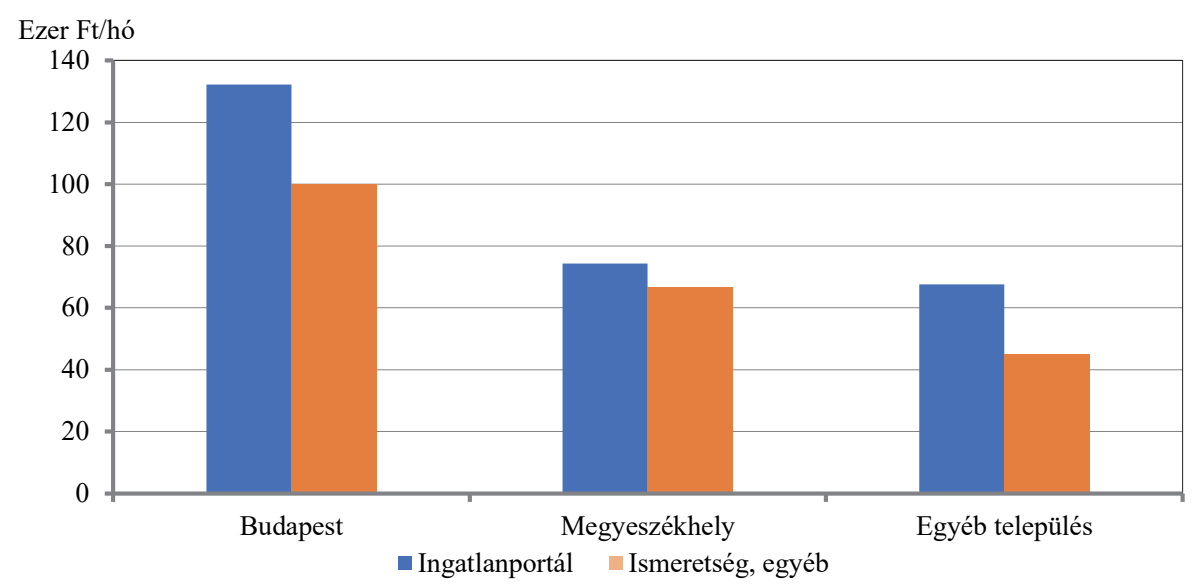

Forrás: KSH [2019].

A lakbérfelmérés kiértékelése során felmerült az igény, hogy az árak időbeli alakulásáról átfogóbb információkra lenne szükség. A $K S H$ [2019] kiadvány az átlagos fajlagos lakbérek alakulását elemzi 2015 és 2018 között településtípusonként, éves bontásban, a bérleti szerződés létrejöttének időpontját véve alapul. A felmérés alapján kissé eltérő folyamatok játszódtak le Budapesten az ország többi településéhez képest: míg utóbbiakban például 2016 és 2017 között stagnált, Budapesten stabilan emelkedett a fajlagos bérleti díj. Kiderült, hogy a bérleti díjak hajlamosak a „beragadásra”, vagyis akik hosszabb ideje bérlői egy lakásnak, azok lakbérszintje kimutathatóan elmarad az aktuálisan létrejövő új bérletekétöl. Ez alapján lehetővé vált a stock- és a flow-alapú számítások megkülönböztetése.

\subsection{A KSH-ingatlan.com lakbérindex}

A 2018-as lakbérfelmérés a további lakbérstatisztikák szempontjából kitért még egy fontos tényezőre, az ingatlanhirdetésre. A KSH [2019] kiadvány szerint míg a községekben és városokban a rokonok, illetve ismerősök révén létrejövő kapcsolat volt kulcsfontosságú a bérleti szerződés szempontjából, Budapesten a bérlők több mint fele, a megyeszékhelyeken több mint egyharmada ingatlanportálokon keresztül jutott bérleményéhez. Az ingatlanportálok hirdetéseivel megfigyelhetővé váltak a bérleti piac alapvető folyamatai, és ez a tény vezetett 2019-ben a KSH és az ingatlan.com együttmüködéséhez, melynek végső célja kísérleti statisztikák készítése, 
valamint a lakbérek időbeli alakulásának nyomon követése volt. A kísérleti statisztika az elmúlt évek növekvő igényére reagált, mely szerint szükség van pontosabb, átláthatóbb adatközlési formákra a lakásbérleti díjak alakulását illetően.

Az együttmüködés keretében az ingatlan.com ingatlanportál elérhetővé tette hirdetési adatbázisát a statisztikai hivatal számára; az ennek eredményeként létrejött lakbérindex, egyéves kísérleti szakasz után, 2020 augusztusában jelent meg elöször (KSH [2020]). Az adatok 2015 májusától állnak rendelkezésre, és az ezekre épített indexeket 2015-ös bázissal, hedonikus regressziós módszerrel, havi rendszerességgel számítja a KSH. Fontos megjegyezni, hogy a mutatók kínálati indexként értelmezendők, azaz adott hónap kínálati árait tükrözik, és a véglegesen kialkudott árról csak korlátozott számú megfigyelés áll rendelkezésre. A $K S H$ [2020] szerint a kínálati és végleges ár között nem volt a vizsgált időszakban szignifikáns eltérés.

A kísérleti statisztika keretében, különböző rétegződésekkel, többféle indexet is közölt a hivatal. Az országos lakbérindex a budapesti kerületcsoportok (budai hegyvidéki kerületek, budai egyéb kerületek, pesti belső kerületek, pesti átmeneti kerületek, pesti külső kerületek) és a magyarországi statisztikai régiók indexeinek súlyozásából, míg a budapesti index kizárólag a fóváros öt kerületcsoportjából számítódik, ezeket külön-külön is közli a KSH.

A hazai lakbérstatisztikai adatközlések föként a budapesti lakbérekre fókuszálnak. Ez a megfigyelések számából is adódik; ahogy a 6. ábra is mutatja, azok több mint 60 százaléka a fővárosra koncentrálódik, míg a megyei városok összesen az éves megfigyelések 20-30 százalékát teszik ki (KSH [2020]).
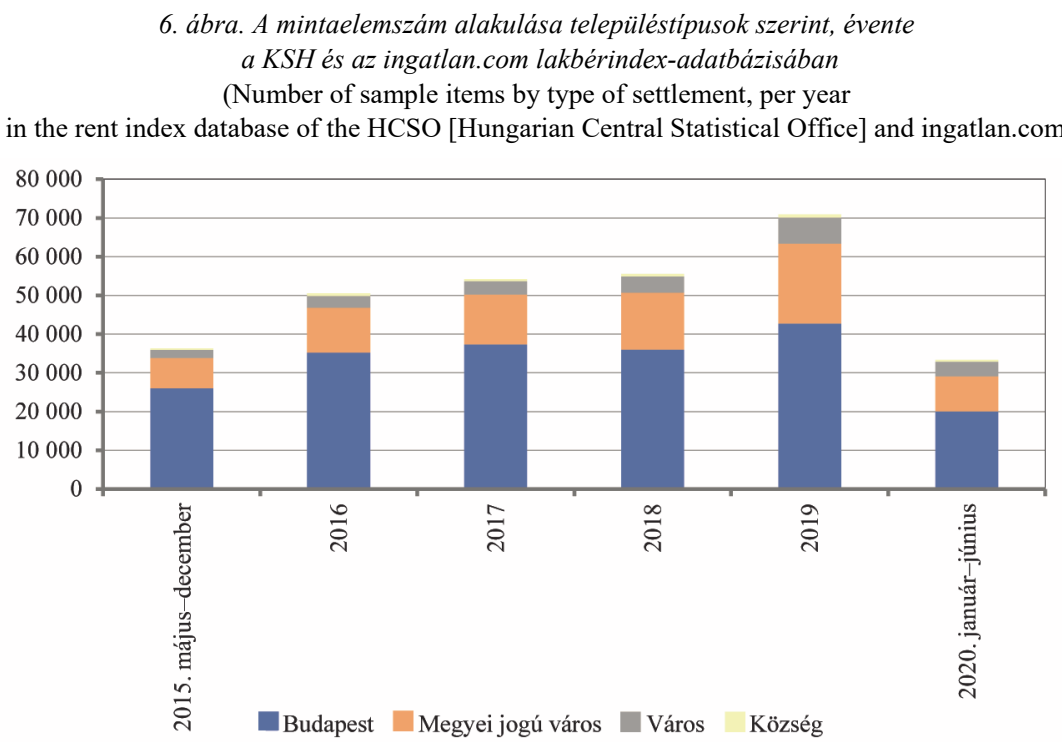

Forrás: $K S H$ [2020]. 
A területi elhelyezkedésen kívül az ingatlanhirdetési adatbázisban különbségek fedezhetők fel a magánszemélyek és az ingatlanirodák által kirakott hirdetések között. A professzionális kiadók és a magánszemélyek kiadásra szánt ingatlankínálaténak minősége eltérö lehet, így például az ingatlanirodás ajánlatban gyakrabban elöfordul luxuskivitelü ingatlan bérleti hirdetése. A vizsgált időszakban körülbelül kétszer annyi irodai hirdetés volt, mint magánhirdetés. Így a bérleti piacon hirdetők szerint is nyomon követhető az árváltozás.

A különböző indexek, melyeket a KSH közöl, trend szerint megegyeznek, egyedül az árváltozás ütemében mutatnak marginális különbséget. Ez több okból is adódhat. A legegyszerübb példa a „biztosan kiadott magánhirdetések” árváltozása, ahol a legszükebb megfigyelési csoportot vizsgálhatjuk. Itt csak a magánhirdetőket vesszük figyelembe, azok közül is azokat, akik visszajelezték a hirdetés levételekor, hogy kiadták a lakást - ami nem kötelező egyetlen hirdetőnek sem. Ebből adódóan a mintaelemszám jelentősen alacsonyabb, és az index jóval érzékenyebb az időszakos árváltozásokra. Ugyanakkor a biztosan kiadott lakások árváltozására vonatkozó adatok fontos információkat nyújtanak, mivel azok összehasonlíthatók a teljes kínálati ár alakulásával.

\section{További alternatív felhasználások - a lakásárak és lakbérek közötti kapcsolat}

A továbbiakban néhány, a nemzetközi irodalomban használt módszertant ismertetek, melyeket a lakbéradatokat felhasználva jövőbeli kutatásokban is hasznosítani lehet a hazai ingatlanpiaci helyzet elemzésére.

A lakbérekről készült statisztikai adatgyüjtésekre alapozva több tanulmány is készült a lakbér-lakásár arányról, annak prediktív képességéröl a lakáspiacra vagy akár a reálgazdaságra. Az alapötlet Campbell és Shiller [2001], illetve a dinamikus Gordon-modell következtetéseiből származik. A dinamikus Gordon-modell (Campbell-Shiller [1988]) szerint a lakbér-lakásár aránynak meg kell egyeznie a jelenidőre diszkontált várható lakhatásból származó bevételek („lakbér”) és az eszköz várhatóérték-növekedésének összegével.

Campbell és Shiller [2001] 130 év tőkepiaci adatát felhasználva tízéves periódusokra osztva vizsgálták az árakat. Megállapították, hogy az osztalék-ár arány - amely az előzők alapján megfeleltethető a lakbér-lakásár aránynak - megbízható előrejelzője volt a tőzsdei áraknak és a fizetett osztalékoknak. Pénzügyi szemléletben a részvény birtoklásának diszkontált értéke két részre bontható: egyrészt a tulajdonlás alatt végbement árnövekedésből származó bevételre (azaz tőkenyereségre), más-

STATISZTIKAI SZEMLE, 100. ÉVFOLYAM 1. SZÁM 68-91. OLDAL DOI: 10.20311/stat2022.1.hu0068 
részt az eszköztartás alatt kapott osztalékra. Míg az első rész a lakás (reál-) árának növekedéséből származik, a lakásból származó osztalék a lakbér-lakásár aránynak feleltethető meg (Davis-Lehnert-Martin [2008]).

Campbell et al. [2009] az ingatlanpiaci árak előrejelzésére és az árváltozások mérésére vektorautoregressziós (VAR-) modellt, illetve varianciadekompozíciót készítettek az 1975 és 2007 közötti éves lakáspiaci árakra. Az éves lakbér-lakásár hányados logaritmusára illesztett VAR-modelljükben a lakhatásból származó megtérülés és a prémium ráta mellett szerepelt még a lakbérnövekedés éves üteme, az egy főre jutó reál-GDP, a népesség éves növekedése és a foglalkoztatás éves növekedési üteme. A modellbecslés eredményét mutatja a 6 . ábra, ahol a folytonos vonal jelöli a tényadatot, a szaggatott vonal pedig az elöre jelzett értékeket. Jól látható, hogy a két idősor közötti diszkrepancia viszonylag egyenletes, azonban a becsült és a tényleges érték közötti eltérés 1997 körül nőni kezd; erre a szerzők több magyarázatot is találtak. Egyrészt 2000 után egy addig soha nem látott szintre csökkent a lakbér-lakásár hányados. Shiller [2015] ezt egy lakásárbuborék meglétével magyarázta, ugyanis ebben az időszakban a lakásárak egyáltalán nem tükrözték a piaci fundamentumokat. Másrészt a lakásárak növekedéséből következhetett, hogy a piaci várakozások is megváltoztak, ami szintén befolyásolhatta a modell pontosságát. Harmadrészt a kamatok és a lakáspiac kockázati prémiuma közötti kovariancia miatt a prémium elörejelezhetősége a piaci boom időszakában erősen romlott.

7. ábra. A VAR-modell előrejelzése (szaggatott vonal) és tényadat (folytonos vonal) a lakbér-lakásár hányados logaritmusára (VAR model prediction [dashed line] and actual data [solid line] for the logarithm of the rent-housing price ratio)

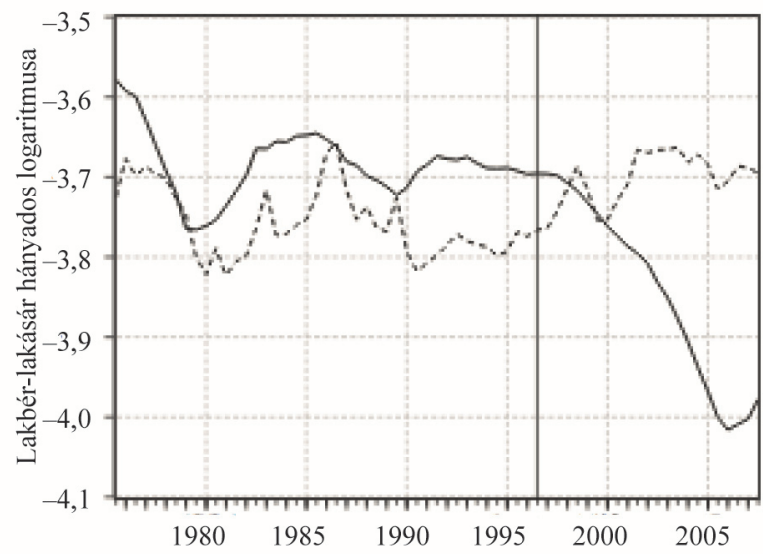

Forrás: Campbell et al. [2009]. 
Engsted és Pedersen [2015] Campbell et al. [2009] alapján elemezték 18 OECD-ország lakáspiacát, illetve azt, hogy az előrejelezhetőségben van-e eltérés a vizsgált országok piacai között. Eredményeik szerint a lakbér-lakásár hányados képes jól elöre jelezni a nominális lakbérváltozást, azonban a reálárakat csak néhány országban tudja befolyásolni. Azokban az országokban, ahol a reál-lakásárak prediktálása jól működik, maga a lakbér-lakásár arány rendkívül jól jelzi előre az infláció alakulását; ez a hatás érvényesülhet valószínüleg a reál-lakbér elörejelzési mechanizmusban is.

A bér-ár arány azonban nem feltétlen hatékony előrejelző az egyes alpiacokon. Plazzi, Torous és Valkanov [2010] a kereskedelmi ingatlanpiacon vizsgálták a bérleti díj-ár arányt: a várható bérleti díj variabilitása tanulmányukban 45 százalékban magyarázta a tényleges bérleti díj változását. Azonban a bérleti díj-ár arány csak marginálisan volt informatív az irodai piacon, az ipari és kiskereskedelmi ingatlanok árváltozását pedig egyáltalán nem magyarázta.

Összességében tehát elmondható, hogy a lakbérek alakulásáról szerzett új információ birtokában számos új kísérleti adatfelvétel végezhető el hazai környezetben is. Megjegyzendő azonban, hogy jelenlegi stádiumban kevés időszakra áll rendelkezésre adat a lakbérekről, így a hosszabb távú idősoros, trendszerủ összefüggések vizsgálata még várat magára.

\section{5. Összegzés}

A tanulmányban összegeztem a hazai lakbérstatisztika történetét, annak közlési módjait és felhasználását. Az elmúlt közel 150 év alatt a folyamatosan változó igények, valamint az infokommunikációs technológia és statisztikai módszertan fejlődése nagy változásokat hozott az adatközlésben. Fontos azonban látni, hogy a régi statisztikai adatközléseknek sincs okuk szégyenkezni. A jelen írásomban is sokat tárgyalt, Szádeczky-Kardoss Tibor által írt 1933-as tanulmány részletesen vizsgálja a különbözö társadalmi rétegek által bérelt lakások tulajdonságát, azok árfekvését, nemcsak statisztikai, de társadalompolitikai elemzést is készítve ezáltal a lakáshelyzetröl.

A XX. század elejéig mindössze az üresen álló lakások kínálati bérleti díját írták össze, a tényleges lakbérek budapesti összeírására az 1920-as években került először sor. Az első részletes lakbérfelmérést az 1930-as népszámlálás alapján készítették, amelyet részletesen bemutattam, az ehhez kötődő módszertani megfontolásokkal együtt. 
A második világháború után a lakbérstatisztika háttérbe szorult, elsősorban az árak szabályozása miatt. 1989-ig lényegében az árváltozás központilag ment végbe, a szabadon megállapítható, ún. szabad bérủ lakások aránya vagy legalábbis láthatósága ekkor marginális volt az állami, illetve üzemi tulajdonú lakások mellett. Az albérleti uzsoráról a hivatalos statisztika nem vett tudomást, létezéséről csak a kor szociográfiáiból értesülhetünk. 1989-től kezdődően a szabad piac megjelenésével egyre nagyobb igény mutatkozott a bérleti díjak statisztikája iránt. A gazdaságstatisztikai elszámolások is új igényt jelentettek, melyeket kérdőíves felmérésekkel elégítettek ki. A KSH 2018-ban egy előzetes kutatás keretében vizsgálta a lakásbérleti piac müködését, majd 2020-ban az ingatlan.com-mal kötött megállapodás lehetővé tette a lakbérindex publikálását is.

A tanulmány negyedik fejezetében - a teljesség igénye nélkül - igyekeztem olyan további alkalmazási lehetőségeket felsorolni, amelyeket jelenleg még nem használnak a magyar statisztikai és közgazdasági irodalomban, azonban implementálásuk hasznos lehet a hazai lakáspiaci vizsgálatok során. Így például Magyarországon még nem terjedt el az általam bemutatott lakbér-lakásár arány mérése és elemzése, mely téma további kutatások tárgya lehet.

\section{Irodalom}

ASCHER, S. [1918]: Die Wohnungsmieten in Berlin von 1880-1910 - Eine statistische Untersuchung als Beitrag zur Theorie der Miete. Berlin.

Bresztovszky E. [1909]: Magyarország fekete statisztikája. In: Természet és Társadalom VIII. Huszadik Század Szerkesztősége. Budapest.

BéKés, G. - Horváth, Á. - SÁPI, Z. [2016]: Flood Risk and Housing Prices: Evidence from Hungary. CERS-IE Working Papers 1620. Institute of Economics, Centre for Economic and Regional Studies. Budapest.

Bonnet, O. - Bono, P. H. - ChAPElle, G. - WASMer, E. [2014]: Does housing capital contribute to inequality? A comment on Thomas Piketty's capital in the $21^{\text {st }}$ century. Sciences Po Economics Discussion Papers. No. 7. pp. 1-12.

Budapest SzÉKesföváros StatiszTiKai Hivatala [1914]: Az 1906. évi népszámlálás eredményei. Budapesti Statisztikai Közlemények 43. https://adt.arcanum.com/hu/view/BpStat Kozlemenyek_043/?pg=84\&layout=s

Campbell, S. D. - Davis, M. A. - Gallin, J. - Martin, R. F. [2009]: What moves housing markets: A variance decomposition of the rent-price ratio. Journal of Urban Economics. Vol. 66. No. 2. pp. 90-102. http://dx.doi.org/10.1016/j.jue.2009.06.002

Campbell, J. Y. - Shiller, R. J. [1988]: The dividend-price ratio and expectations of future dividends and discount factors. Review of Financial Studies. Vol. 1. No. 3. pp. 195-228. http://dx.doi.org/10.1093/rfs/1.3.195 
CAmpBell, J. Y. - Shiller, R. J. [2001]: Valuation Ratios and the Long-Run Stock Market Outlook: An Update. National Bureau of Economic Research. Cambridge. http://dx.doi.org/ $10.3386 / \mathrm{w} 8221$

DAVIS, M. A. - LehNeRT, A. - MARTIN, R. F. [2008]: The rent-price ratio for the aggregate stock of owner-occupied housing. Review of Income and Wealth. Vol. 54. No. 2. pp. 279-284. https:/citeseerx.ist.psu.edu/viewdoc/download?doi=10.1.1.654.6323\&rep=rep1\&type=pdf

ENGEL, E. [1857]: Die productions- und consumtionsverhaltnisse des königreichs sachsen. Zeitschrift des Statistischen Bureaus des Königlich Sächsischen Ministeriums des Innern. No. 8-9. November. pp. 27-29.

Engsted, T. - Pedersen, T. Q. [2015]: Predicting returns and rent growth in the housing market using the rent-price ratio: Evidence from the OECD countries. Journal of International Money and Finance. Vol. 53. pp. 257-275. http://dx.doi.org/10.1016/j.jimonfin.2015.02.001

FARKAS E. J. [2000]: Népszámlálás és folyamatos lakásstatisztika. Statisztikai Szemle. 78. évf. 10. sz. 842-853. old. https://www.ksh.hu/statszemle archive/2000/2000 10-11/2000 1011_842.pdf

FARKAS E. J. - VAJdA Á. [1990a]: A lakásstatisztikai adatközlések I. Statisztikai Szemle. 68. évf. 1. sz. 67-73. old. http://www.ksh.hu/statszemle_archive/all/1990/1990_01/1990_01_0067_0073.pdf

FARKAS E. J. - VAJDA Á. [1990b]: A lakásstatisztikai adatközlések III. Statisztikai Szemle. 68. évf. 3. sz. 239-253. old. https://www.ksh.hu/statszemle_archive/all/1990/1990_03/1990_03_ 0239 0253.pdf

HoRvÁTH Á. - SzÉKely G. [2009]: Hedonikus módszer alkalmazása a használt lakások áralakulásának megfigyelésében. Statisztikai Szemle. 87. évf. 6. sz. 594-607. old. https://www.ksh.hu/statszemle_archive/all/2009/2009_06/2009_06_594.pdf

HÜtTl A. - PozsonYı P. [2018]: A nemzeti számlák története Magyarországon II. rész - Az Európai Unió követelményeinek teljesítése. Statisztikai Szemle. 96. évf. 3. sz. 292-311. old. http://dx.doi.org/10.20311/stat2018.03.hu0292

KíGYÓsI A. [2007]: A Fővárosi Statisztikai Hivatal szervezete és müködése a XIX. század utolsó harmadában. Statisztikai Szemle. 85. évf. 8. sz. 715-726. old.

KSH (KöZPOnti StatiszTiKai HivatAL) [1955]: Lakásviszonyok, 1954. július 1. Jelentés. Budapest.

KSH [1974]: Az 1973. évi mikrocenzus adatai. Budapest.

KSH [1986]: Lakásváltoztatási szándékok, lakáskörülmények az 1984. évi mikrocenzus alapján. Budapest.

KSH [2001]: Beszámoló a „Lakbérfelvétel 2000” végrehajtásáról, az eredmények feldolgozásáról. Munkaanyag.

KSH [2003]: Beszámoló a 2002. évi lakbérfelvétel végrehajtásáról, az eredmények feldolgozásáról. Munkaanyag.

KSH [2019]: Magánlakásbérlés, bérleti díjak - a 2018. évi lakbérfelmérés föbb eredményei. Statisztikai Tükör. Június 25. http://www.ksh.hu/docs/hun/xftp/stattukor/lakber18.pdf

KSH [2020]: Folyamatban lévö kutatások - Lakbérindex-számítás. https://www.ksh.hu/docs/hun/ xftp/stattukor/lakberindex_szamitas/index.html

KSH [2021]: Fogyasztóiár-indexek a termékek és szolgáltatások részletes csoportjai szerint. https://www.ksh.hu/docs/hun/xstadat/xstadat_evkozi/e_qsf002a.html

STATISZTIKAI SZEMLE, 100. ÉVFOLYAM 1. SZÁM 68-91. OLDAL DOI: 10.20311/stat2022.1.hu0068 
LENCSÉS Á. [2012]: Thirring Gusztáv és az 1906. évi budapesti népszámlálás (150 éve született Thirring Gusztáv). Területi Statisztika. 52. évf. 1. sz. 87-93. old.

LindERMANN, H. [1902]: Die Wohnungsstatistik von Wien und Budapest. In: Verhandlungen des Vereins für Socialpolitik über die Wohnungsfrage und die Handelspolitik. Duncker \& Humblot. Leipzig.

LiSKA T. [1969]: A bérlakás-kereskedelem koncepciója. In: Böröczfy F. (szerk.): Lakáspolitikánkról. Kossuth Kiadó. Budapest. 7-38. old.

MiнÁlyi P. [1981]: Bérlőből tulajdonos. In: Böröczfy F. (szerk.): Lakáspolitikánkról. Kossuth Kiadó. Budapest. 184-203. old.

PIKeTty, T. [2014]: Capital in the Twenty-First Century. Harvard University Press. Cambridge.

Plazzi, A. - Torous, W. - VAlKanov, R. [2010]: Expected returns and expected growth in rents of commercial real estate. Review of Financial Studies. Vol. 23. No. 9. pp. 3469-3519. http://dx.doi.org/10.1093/rfs/hhq069

RAKVÁCS J. [1974]: A lakásbérlet kézikönyve. Közgazdasági és Jogi könyvkiadó. Budapest.

SchwaBe, A. [1868]: Das Verhältnis von Miete und Einkommen in Berlin. Berliner Stadt- und Gemeunde-Kalender und städtusches Jahrbuck. pp. 264-267.

Shiller, R. J. [2015]: Irrational Exuberance: Revised and Expanded. Third edition. Princeton University Press. New Jersey.

SINGER, H. W. [1937]: Income and rent: A study of family expenditure. The Review of Economic Studies. Vol. 4. No. 2. pp. 145-154. http://dx.doi.org/10.2307/2967611

SzÁDECZKY-KARDOSS T. [1933]: A lakbérviszonyok alakulása Budapesten. Statisztikai Közlemények. 54. kötet. Központi Statisztikai Hivatal. Budapest.

SZELÉnYi I. - KonRÁD Gy. [1985]: Az értelmiség útja az osztályhatalomhoz. Áramlat Kiadó. Budapest.

SzÉKELy G. [2020]: Száz év a magyarországi lakásstatisztikában. Statisztikai Szemle. 98. évf. 6. sz. 642-664. old. http://dx.doi.org/10.20311/stat2020.6.hu0642

VAlluCh T. [2013]: Magyar hétköznapok. Fejezetek a mindennapi élet történetéböl a második világháborútól az ezredfordulóig. Napvilág Kiadó. Budapest.

VÉRTESY L. [2018]: A lakhatás megfizethetösége: lakbérek és albérletpiac. Pénzügyi mühelytanulmányok 3. Budapesti Műszaki és Gazdaságtudományi Egyetem. Budapest.

VITA L. [2000]: A hedonikus árindexröl. In: Hunyadi L. (szerk.): Fél évszázad a statisztika szolgálatában. Központi Statisztikai Hivatal. Budapest. 34-40. old. 